\title{
Viability of Cyperus rotundus L. tubers after application of herbicide in pre- and postemergence*
}

\section{Viabilidade de tubérculos de Cyperus rotundus L. após a aplicação de herbicidas em pré e pós-emergência}

\author{
Ana Ligia Giraldeli ${ }^{1,2}$ (1) (https://orcid.org/0000-0002-7452-0370) \\ André Felipe Moreira Silva ${ }^{3 * *}$ (1) (https://orcid.org/0000-0002-4846-8089) \\ Felipe Carrara de Brito' (1) (https://orcid.org/0000-0002-8884-013X) \\ Robson Josadaque Nogueira de Lima' (1) (https://orcid.org/0000-0001-9766-6703) \\ Beatriz Sizilio dos Santos' (1) (https://orcid.org/0000-0001-7278-4658) \\ Diogo Alexandre Góes de Oliveira' (1) (https://orcid.org/0000-0002-5351-0886) \\ Ricardo Victoria Filho' (1) (https://orcid.org/0000-0002-2185-8773)
}

\begin{abstract}
Chemical management is the most widely adopted technique to control weeds in sugarcane crops. Purple nutsedge (Cyperus rotundus L.) is among the most difficult species to control. Herbicides need to be absorbed and translocated in a sufficient amount for the tuber chain to be effective. Thus, this study aimed to evaluate the effectiveness of the herbicides sulfentrazone, diclosulam, imazapic, imazapyr, halosulfuron, ethoxysulfuron, monosodium methyl arsenate (MSMA), and 2,4-dichlorophenoxyacetic acid (2,4-D) in controlling C. rotundus and reducing the viability of its tubers. The experiment was carried out in a greenhouse in a completely randomized design, with nine treatments and four replications. The herbicides sulfentrazone (800 g active ingredient $\left.-\mathrm{ai} \cdot \mathrm{ha}^{-1}\right)$, diclosulam (193.17 $\mathrm{g}$ ai $\left.\cdot \mathrm{ha}^{-1}\right)$,

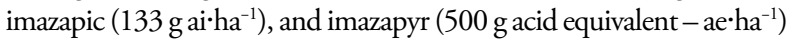
were applied in preemergence at five days after planting the tubers, while halosulfuron (112.5 $\mathrm{g}$ ai $\left.\mathrm{ha}^{-1}\right)$, ethoxysulfuron (135 $\mathrm{g}$ ai $\left.\cdot \mathrm{ha}^{-1}\right)$, MSMA (1,975 $\mathrm{g}$ ai $\left.\cdot \mathrm{ha}^{-1}\right)$, and 2,4-D (1,340 $\mathrm{g}$ ae $\left.\cdot \mathrm{ha}^{-1}\right)$ were applied in postemergence ( 4 to 5 leaves). The parameters visual control, shoot dry matter, number of tubers and bulbs, weight of tubers + bulbs, number of epigeal manifestations, and tuber viability were analyzed. The herbicides diclosulam, halosulfuron, and ethoxysulfuron provided $100 \%$ control of the shoot at 90 days after application (DAA). All herbicides reduced the number of bulbs, weight of tubers + bulbs, and shoot dry matter. The herbicides sulfentrazone, imazapic, halosulfuron, ethoxysulfuron, and MSMA provided the highest reduction in tuber viability.
\end{abstract}

KEYWORDS: control; weeds; purple nutsedge; tetrazolium.
RESUMO: O manejo químico é o mais adotado para o controle de plantas daninhas na cultura da cana-de-açúcar. Entre as espécies de difícil controle está a tiririca (Cyperus rotundus L.). Os herbicidas utilizados precisam ser absorvidos e transportados para a cadeia de tubérculos em quantidades suficientes para serem eficazes. Assim, objetivou-se com este estudo avaliar a eficácia dos herbicidas sulfentrazona, diclosulam, imazapique, imazapir, halossulfurom, etoxissulfurom, metano arseniato ácido monossodico (MSMA) e ácido diclorofenoxiacético (2,4D) no controle de $C$. rotundus e na reduçáo da viabilidade de seus tubérculos. O experimento foi realizado em casa de vegetação, em delineamento inteiramente randomizado, com nove tratamentos e quatro repetiçōes. Os herbicidas sulfentrazone (800 g ingrediente ativo - i.a. ha $\left.{ }^{-1}\right)$, diclosulam $\left(193,17 \mathrm{~g}\right.$ i.a. $\left.\cdot \mathrm{ha}^{-1}\right)$, imazapique (133 g i.a. ha $\left.^{-1}\right)$ e imazapir $\left(500 \mathrm{~g}\right.$ equivalente - e.a. $\left.\cdot \mathrm{ha}^{-1}\right)$ foram aplicados cinco dias após o plantio dos tubérculos em pré-emergência, enquanto que o halossulfurom (112,5 g i.a. $\left.\cdot \mathrm{ha}^{-1}\right)$, etoxissulfurom $\left(135 \mathrm{~g}\right.$ i.a. $\left.\cdot \mathrm{ha}^{-1}\right)$, MSMA (1.975 g i.a. ha $\left.{ }^{-1}\right)$ e 2,4-D (1.340 g e.a. ha $\left.^{-1}\right)$ foram aplicados em pós-emergência (4 a 5 folhas). Foram feitas avaliaçôes visuais de controle, massa seca da parte aérea, número de tubérculos e bulbos, peso de tubérculos + bulbos, número de manifestaçôes epígeas e viabilidade de tubérculos. Aos 90 dias após a aplicação (DAA) os herbicidas diclosulam, halossulfurom e etoxissulfurom propiciaram $100 \%$ de controle da parte aérea. Todos os herbicidas reduziram o número de bulbos, peso de tubérculos + bulbos e massa seca da parte aérea. Sulfentrazona, imazapic, halossulfurom, etoxissulfurom e MSMA foram os herbicidas que mais reduziram a viabilidade dos tubérculos.

PALAVRAS-CHAVE: controle; plantas daninhas; tiririca; tetrazólio.

\footnotetext{
"Universidade de São Paulo - Escola Superior de Agricultura "Luiz de Queiroz" - Departamento de Produção Vegetal - Piracicaba (SP), Brazil

"Universidade Estadual de Londrina - Departamento de Agronomia - Londrina (PR), Brazil

${ }^{3}$ Crop Science Pesquisa e Consultoria Agronômica - Palotina (PR), Brazil

*This paper is part of the doctoral thesis of the first author.

**Corresponding author: afmoreirasilva@hotmail.com

Received on: 6/26/2019. Accepted on: 9/7/2020
} 


\section{INTRODUCTION}

Purple nutsedge (Cyperus rotundus L.) can represent 60 to $80 \%$ of the weed population in sugarcane cultivation, causing 20 to $30 \%$ of yield losses when its control is delayed by eight weeks (PEERZADA, 2017). Its control using herbicides and hoeing is difficult because it reproduces almost exclusively via rhizomes, tubers, and basal bulbs (RAHNAVARD et al., 2010); also, because tubers can have different levels of dormancy (BALOCH et al., 2015). Moreover, soil disturbance with a consequent rupture of the tuber chain ends up leading to the breaking of rhizomes, guaranteeing the spread of the species (BANGARWA et al., 2008).

In Brazil, some herbicides are registered for use in pre- or postemergence (initial, late, or directed spraying) of sugarcane and $C$. rotundus, such as sulfentrazone, diclosulam, imazapic, imazapyr, halosulfuron, ethoxysulfuron, monosodium methyl arsenate (MSMA), and 2,4-dichlorophenoxyacetic acid (2,4-D), trifloxysulfuron and glyphosate (RODRIGUES; ALMEIDA, 2018). However, the effectiveness of chemical management depends on the herbicide rate, number of applications, the tuber bank present in the soil, and cultivation practices (PEERZADA, 2017).

The herbicide needs to be absorbed and translocated in a sufficient amount to the site of action to ensure effective weed control. Many factors can interfere with these processes, such as the environmental conditions, leaf surface composition, physicochemical characteristics of the herbicides, and availability of the product at the absorption site (MONQUERO; HIRATA, 2014). One of the main difficulties in the case of C. rotundus is in the translocation of products throughout the tuber chain. Thus, tuber viability studies are necessary to evaluate the potential of herbicides to reach the sites of action.

The application of sulfentrazone ( $700 \mathrm{~g}$ ai $\left.\cdot \mathrm{ha}^{-1}\right)$ to control C. rotundus reduced the number of tubers and sprouts, plant height, and fresh biomass of the root, tubers, and shoot compared to the control under the absence of $15 \mathrm{t} \cdot \mathrm{ha}^{-1}$ of sugarcane straw (NOVO et al., 2008a). The use of $110 \mathrm{~g}$ ai.ha ${ }^{-1}$ of imazapic was sufficient to keep the percentage of soil cover below that of the control treatment at 60 days after application (DAA). In addition to reducing the number, dry matter, viability of tubers, and shoot dry matter of purple nutsedge plants (AZANIA et al., 2006), SIMONI et al. (2006) also observed a reduction in the number of plants, basal bulbs, and dry matter of bulbs, rhizome + root, and shoot of $C$. rotundus after the application of sulfentrazone $\left(800 \mathrm{~g}\right.$ ai $\left.\cdot \mathrm{ha}^{-1}\right)$ and imazapic

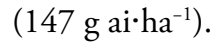

SILVA et al. (2014) studied the effectiveness of the herbicides halosulfuron, sulfentrazone, and imazapic at rates of $112.5,800$, and $147 \mathrm{~g}$ ai.ha ${ }^{-1}$, respectively, and five weed densities $\left(6,18,24,30\right.$ and 36 tubers.pot $\left.{ }^{-1}\right)$ to control C. rotundus. The three herbicides provided a reduction in the tuber dry matter, but sulfentrazone provided the highest reduction of this variable (lower than $5 \mathrm{~g} \cdot \mathrm{pot}^{-1}$ ) at $60 \mathrm{DAA}$ among all tested densities. In addition, sulfentrazone promoted the highest reduction in tuber density and provided the highest number of dead tubers at densities above 24 tubers.pot ${ }^{-1}$.

Therefore, considering the hypothesis that effective control of the shoot of $C$. rotundus does not necessarily indicate a reduction in tuber viability, this study aimed to evaluate the effectiveness of pre-or postemergence herbicides applied on C. rotundus, as well as the effect of the herbicides on tuber viability.

\section{MATERIAL AND METHODS}

The experiment was carried out in a greenhouse located in Piracicaba, state of São Paulo (SP), Brazil (22 $22^{\circ} 47.8^{\prime \prime} S$ and $47^{\circ} 37^{\prime} 14.6^{\prime \prime} \mathrm{W}$, with an altitude of $547 \mathrm{~m}$ ), from November 2017 to February 2018. The results of the soil chemical and physical analyses are shown in Table 1 . The soil was classified as clayey.

The experimental design was completely randomized, with four replications and experimental units consisting of one-liter plastic pots filled with sieved soil. Four tubers weighing between 1 and $2 \mathrm{~g}$ were placed in each pot at a depth of $3 \mathrm{~cm}$. The treatments are shown in Table 2.

The treatments were applied in an experimental herbicide spray chamber driven by an electric motor, set to a constant pressure of $40 \mathrm{Psi}$, and equipped with a Teejet XR80.02 flat fan spray tip positioned at $50 \mathrm{~cm}$ in height of the target, providing a spray solution volume of $200 \mathrm{l} \cdot \mathrm{ha}^{-1}$.

Plant control was evaluated at $7,15,30,45,60,75$, and 90 DAA by assigning visual scores to each experimental unit: 0 to $40 \%$ (poor or absent control), 41 to $60 \%$ (regular control), 61 to $70 \%$ (sufficient control), 71 to $80 \%$ (good control), 81 to $90 \%$ (high control), and 91 to $100 \%$ (excellent control) (ALAM, 1974). The number of epigeal manifestations with a size equal to or higher than $1 \mathrm{~cm}$ was also counted during the evaluations.

Table 1. Physical and chemical characteristics of the soil. Piracicaba, SP, Brazil, 2017/18.

\begin{tabular}{|c|c|c|c|c|c|c|c|c|c|c|c|}
\hline P (Resin) & O.M. & $\mathrm{pH}$ & K & $\mathrm{Ca}$ & $\mathrm{Mg}$ & Al & $\mathrm{H}+\mathrm{Al}$ & SB & CEC & $\mathbf{v}$ & $\mathrm{m}$ \\
\hline $\mathrm{mg} \cdot \mathrm{dm}^{-3}$ & $\mathrm{~g} \cdot \mathrm{dm}^{-3}$ & $\mathrm{CaCl}_{2}$ & \multicolumn{7}{|c|}{$\mathrm{mmol}_{\mathrm{c}} \cdot \mathrm{dm}^{-3}$} & \multicolumn{2}{|c|}{$\%$} \\
\hline 7 & 42 & 4.9 & 1.69 & 48.49 & 14.65 & 0.26 & 22 & 64.83 & 86.83 & 74.66 & 0.4 \\
\hline Sand & & & \multicolumn{5}{|c|}{ Silt } & \multicolumn{4}{|c|}{ Clay } \\
\hline $35.3 \%$ & & & \multicolumn{5}{|c|}{$23.7 \%$} & \multicolumn{4}{|c|}{$41 \%$} \\
\hline
\end{tabular}


The plant shoots were cut close to the soil surface at $90 \mathrm{DAA}$, packed in properly identified paper bags, and submitted to drying in a forced-air circulation oven at $65^{\circ} \mathrm{C}$ for $48 \mathrm{~h}$ to determine the dry matter. Subsequently, the soil present in the pots was sieved to separate tubers and bulbs from the soil. They were then washed under running water, counted, and weighed.

The tubers were maintained at ambient temperature until they lost $15 \%$ moisture. Then, whole tubers were placed in the experimental units consisting of 200-mL plastic cups together with $50 \mathrm{~mL}$ of $0.5 \%$ tetrazolium solution for $24 \mathrm{~h}$ and maintained in a germinator with a constant temperature of $35^{\circ} \mathrm{C}$ in the absence of light. At the end of this period, the tubers were removed from the tetrazolium solution, washed in running water, and cut longitudinally to allow the visual evaluation of the presence and intensity of staining along its surface. They were classified for the staining in the bud and central regions, according to scores from 1 to 5 , as follows: $1-0 \%, 2-1$ to $30 \%, 3-31$ to $60 \%, 4-61$ to $90 \%$, and 5-91 to $100 \%$ (SILVA et al., 2009).

The data regarding the number of epigeal manifestations, number of bulbs and tubers, weight of tubers + bulbs, and shoot dry matter were subjected to analysis of variance and F-test $(p<0.05)$ and, when significant, the means were compared by the TUKEY's (1949) test $(p<0.05)$ (PIMENTEL-GOMES; GARCIA, 2002). The data of control and tuber viability were assessed descriptively.

\section{RESULTS}

The visual analysis of the shoot control of $C$. rotundus showed excellent control (91-100\%) for the herbicides diclosulam, imazapic, imazapyr, halosulfuron, and ethoxysulfuron from 45 DAA. Sulfentrazone provided a control considered regular (41-60\%) in the evaluations at 7 and 15 DAA, being classified from 0 to $40 \%$ after this period. The herbicide MSMA provided a good control at $30 \mathrm{DAA}(72.5 \%)$, but with a score reduction from this evaluation. 2,4-D resulted in increasing percentages of control throughout the evaluations, with a maximum score at 75 DAA (95.5\%) (Table 3).

Treatments with halosulfuron and ethoxysulfuron resulted in the absence of plants with epigeal manifestations from

Table 2. Treatments applied at pre- or postemergence of $C$. rotundus. Piracicaba, SP, Brazil, 2017/18.

\begin{tabular}{lccc} 
Herbicide & Commercial product & Rate $^{1}$ & \multicolumn{1}{c}{ Time of application $^{2}$} \\
Control & - & - & - \\
\hline Sulfentrazone & Boral 500 SC & 800 & Pre- $^{-}$ \\
\hline Diclosulam & Coact & 193.17 & Pre- \\
\hline Imazapic & Plateau & 133 & Pre- \\
\hline Imazapyr & Contain & 500 & Pre- \\
\hline Halosulfuron & Sempra & 112.5 & Post- \\
\hline Ethoxysulfuron & Gladium & 135 & Post- \\
\hline MSMA & Volcane & 1,975 & Post- \\
\hline 2,4-D & DMA 806 BR & 1,340 & Post- \\
\hline
\end{tabular}

${ }^{1}$ Rates at $\mathrm{g}$ ai-ha-1 and at ae $\mathrm{ha}^{-1}$ for herbicides 2,4-D and imazapyr; ${ }^{2}$ Time of application: pre (five days after planting) and post ( 22 days after planting; plants with 4 to 5 leaves).

Table 3. Control (\%) of $C$. rotundus plants at 7, 15, 30, 45, 60, 75, and 90 DAA. Piracicaba, SP, Brazil, $2017 / 18$.

\begin{tabular}{lccccrrrr} 
Treatments & $\mathbf{7}$ & $\mathbf{1 5}$ & $\mathbf{3 0}$ & $\mathbf{4 5}$ & 60 & $\mathbf{7 5}$ & 90 \\
\hline Control & 0.00 & 0.00 & 0.00 & 0.00 & 0.00 & 0.00 & 0.00 \\
\hline Sulfentrazone & 55.00 & 55.00 & 32.50 & 26.25 & 8.00 & 13.75 & 12.50 \\
\hline Diclosulam & 78.75 & 91.75 & 96.50 & 98.75 & 98.75 & 100.00 & 100.00 \\
\hline Imazapic & 63.75 & 71.25 & 75.00 & 92.00 & 98.75 & 99.00 & 99.00 \\
\hline Imazapyr & 70.00 & 80.00 & 88.75 & 97.75 & 98.75 & 99.50 & 99.75 \\
\hline Halosulfuron & 16.25 & 73.75 & 98.75 & 99.50 & 100.00 & 100.00 & 100.00 \\
\hline Ethoxysulfuron & 16.25 & 62.50 & 94.00 & 97.50 & 100.00 & 100.00 & 100.00 \\
\hline MSMA & 25.00 & 57.50 & 72.50 & 50.00 & 40.00 & 66.25 & 56.25 \\
\hline 2,4-D & 11.25 & 68.75 & 78.75 & 85.25 & 94.00 & 95.50 & 93.75 \\
\hline Mean & 37.36 & 62.27 & 70.75 & 71.88 & 70.91 & 74.88 & 73.47
\end{tabular}

Scores according to ALAM (1974); DAA: days after application. 
60 DAA. Only diclosulam differed from the control at 15 DAA. Diclosulam, imazapyr, halosulfuron, ethoxysulfuron, and 2,4-D provided a lower number of epigeal manifestations than the control at 30 DAA. All herbicides reduced the number of epigeal manifestations from 45 DAA compared to the control (Table 4).

All treatments provided a reduction in the weight of tubers + bulbs, number of bulbs, and shoot dry matter compared to the control (no application). The herbicides sulfentrazone, imazapic, halosulfuron, ethoxysulfuron, and MSMA promoted the highest reduction in tuber viability, with a score of 3 (31 to $60 \%$ of staining in the bud and central regions), while diclosulam, imazapyr, and 2,4-D provided a score of 4 (61 to $90 \%$ ) (Table 5 and Fig. 1).

\section{DISCUSSION}

Imazapic (133 $\mathrm{g}$ ai $\cdot \mathrm{ha}^{-1}$ ) and halosulfuron (112.5 $\mathrm{g}$ ai $\cdot \mathrm{ha}^{-1}$ ) reduced the number of tubers compared to the control and were classified with a score of 3 (31 to $60 \%$ of staining in the bud and central regions). DURIGAN et al. (2005) observed that sulfentrazone $\left(800 \mathrm{~g}\right.$ ai $\left.\cdot \mathrm{ha}^{-1}\right)$ and imazapic $\left(105 \mathrm{~g}\right.$ ai $\left.\cdot \mathrm{ha}^{-1}\right)$ applied to soil reduced the number of total and viable tubers at 45 and 90 DAA, while halosulfuron $\left(105 \mathrm{~g}\right.$ ii $\left.\cdot \mathrm{ha}^{-1}\right)$ reduced the number of viable tubers at 90 DAA. Halosulfuron affected the third tuber of the chain attached to the epigeal manifestation by 62,54 , and $46 \%$ when the applications were carried out in the young ( 4 to 5 leaves), preflowering ( 5 to 7 leaves), and full flowering stages ( 7 to 8 leaves), respectively.

Table 4. Number of epigeal manifestations of $C$. rotundus at 7, 15, 30, 45, 60, 75, and 90 DAA. Piracicaba, SP, Brazil, $2017 / 18$.

\begin{tabular}{|c|c|c|c|c|c|c|c|}
\hline Treatments & $7^{\mathrm{ns}}$ & $15^{*}$ & $30 *$ & $45^{*}$ & $60 *$ & $75^{*}$ & $90 *$ \\
\hline Control & 12.50 & $16.50 \mathrm{~b}$ & $15.00 \mathrm{c}$ & $19.25 d$ & $13.25 c$ & $14.00 \mathrm{~d}$ & $13.50 c$ \\
\hline Sulfentrazone & 10.50 & 12.00ab & $11.25 a b c$ & $11.50 c$ & $9.50 b$ & $7.75 c$ & $5.50 b$ \\
\hline Diclosulam & 7.25 & $6.75 a$ & $5.50 a b$ & 3.00ab & $0.75 a$ & $0.00 a$ & $0.00 a$ \\
\hline Imazapic & 11.00 & 14.00ab & $11.50 b c$ & $7.25 b c$ & $2.00 a$ & 1.00ab & $0.50 a b$ \\
\hline Imazapyr & 7.50 & $8.25 a b$ & $7.50 a b$ & $4.25 a b$ & $1.00 a$ & $0.50 a$ & $0.25 a$ \\
\hline Halosulfuron & 12.75 & $11.50 a b$ & $4.25 a$ & $0.25 a$ & $0.00 a$ & $0.00 a$ & $0.00 a$ \\
\hline Ethoxysulfuron & 10.25 & $10.25 a b$ & 7.00ab & $1.75 a b$ & $0.00 a$ & $0.00 a$ & $0.00 a$ \\
\hline MSMA & 12.25 & $12.50 a b$ & $10.75 a b c$ & $11.25 c$ & $7.25 b$ & $4.75 b c$ & $3.75 a b$ \\
\hline $2,4-D$ & 13.25 & $13.25 a b$ & $6.00 a b$ & $3.25 \mathrm{ab}$ & $2.75 a$ & $3.25 a b$ & $3.00 \mathrm{ab}$ \\
\hline Mean & 10.80 & 11.67 & 8.75 & 6.86 & 4.05 & 3.47 & 2.94 \\
\hline LSD & 6.29 & 7.82 & 7.14 & 5.86 & 3.36 & 4.22 & 5.02 \\
\hline CV (\%) & 24.47 & 28.19 & 18.36 & 19.0 & 16.73 & 20.54 & 26.2 \\
\hline
\end{tabular}

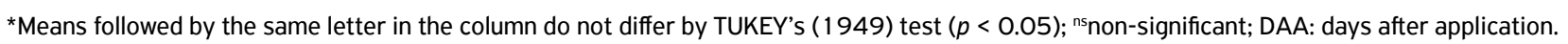

Table 5. Number of bulbs and tubers, weight of tubers + bulbs, shoot dry mass, and viability notes of tubers of $C$. rotundus, at 90 DAA. Piracicaba, SP, Brazil, 2018.

\begin{tabular}{|c|c|c|c|c|c|}
\hline Treatments & $T+B(g)^{*}$ & NT* & NB* & $\begin{array}{c}\text { Shoot } \\
\text { dry mass }(g)^{*}\end{array}$ & Viability \\
\hline Control & $8.94 c$ & $6.00 c$ & $26.50 c$ & $0.73 c$ & 5 \\
\hline Sulfentrazone & $5.91 b$ & $5.25 b c$ & $9.00 \mathrm{~b}$ & $0.44 b$ & 3 \\
\hline Diclosulam & $2.21 \mathrm{a}$ & 4.00ab & $0.00 a$ & $0.00 a$ & 4 \\
\hline Imazapic & $3.80 a b$ & $3.75 a b$ & $4.25 a$ & $0.00 a$ & 3 \\
\hline Imazapyr & $2.31 \mathrm{a}$ & $3.25 a$ & $1.25 a$ & $0.00 a$ & 4 \\
\hline Halosulfuron & $2.91 a$ & 4.00ab & $1.25 a$ & $0.00 a$ & 3 \\
\hline Ethoxysulfuron & $2.90 a$ & 4.00ab & $2.00 a$ & $0.00 a$ & 3 \\
\hline MSMA & $2.88 a$ & $3.50 a b$ & $4.25 a$ & $0.10 a$ & 3 \\
\hline $2,4-D$ & $3.30 a$ & $4.00 a b$ & $3.00 a$ & $0.13 a$ & 4 \\
\hline Mean & 3.91 & 4.19 & 5.72 & 0.15 & \\
\hline LSD & 2.50 & 1.78 & 4.44 & 0.21 & \\
\hline CV (\%) & 26.90 & 17.92 & 22.14 & 3.48 & \\
\hline
\end{tabular}

*Means followed by the same letter in the column do not differ by TUKEY's (1949) test $(p<0.05)$; T + B: weight of tubers + bulbs; NT: number of tubers; NB: number of bulbs; DAA: days after application. 


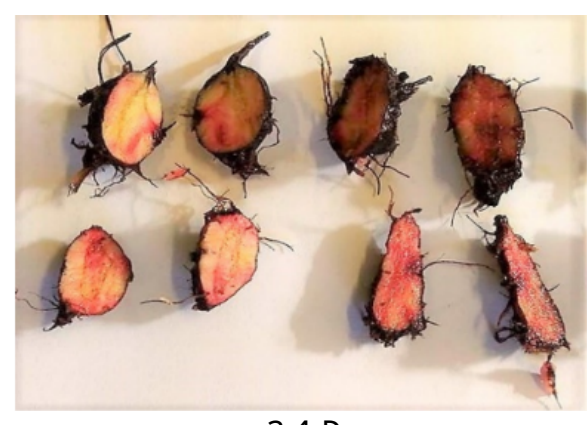

$$
\text { 2,4-D }
$$

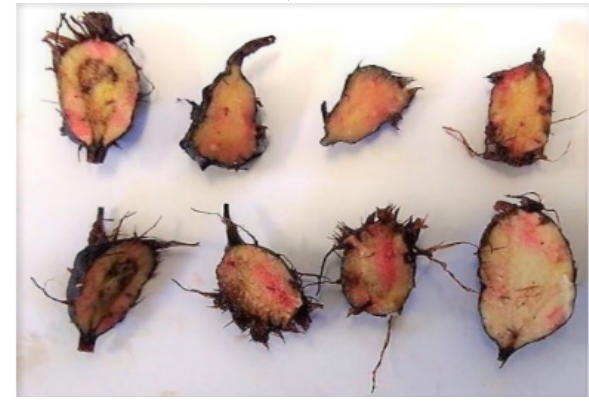

Ethoxysulfuron

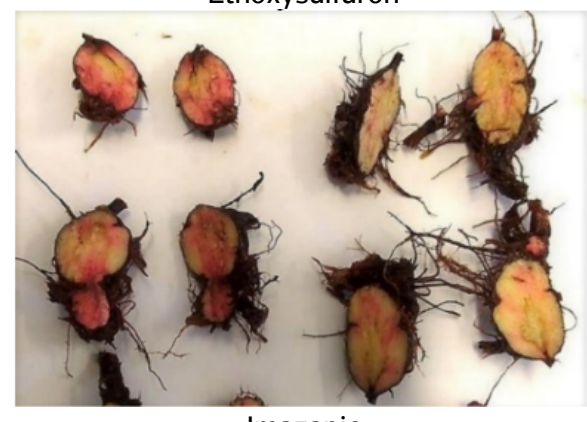

Imazapic
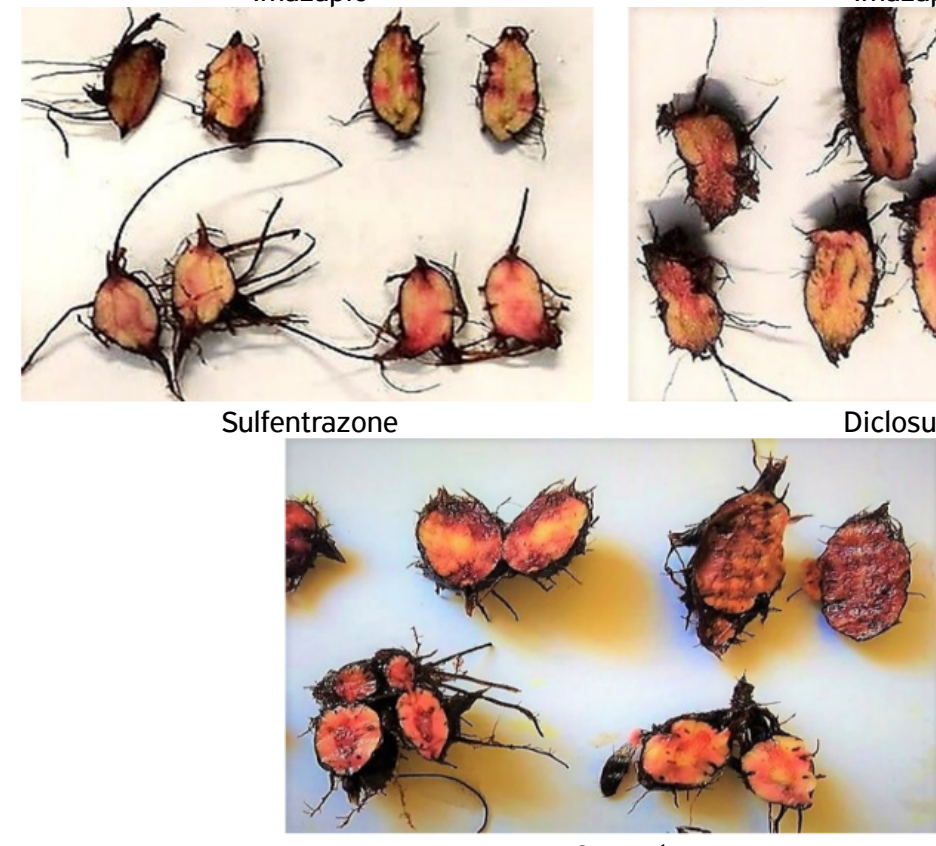

Control

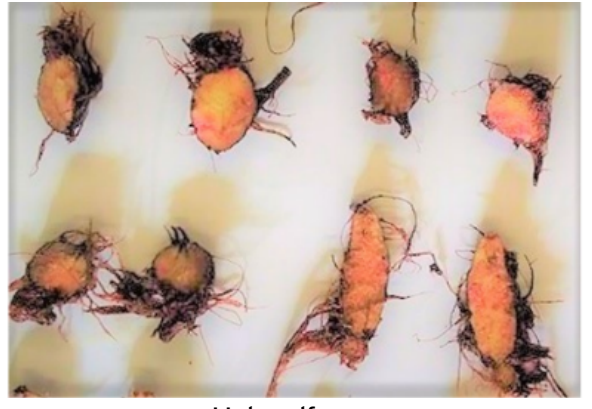

Halosulfuron

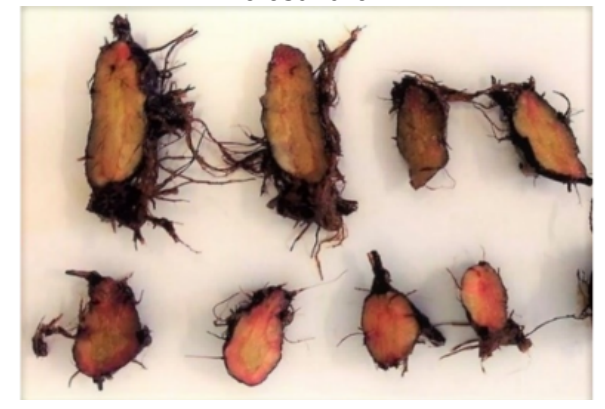

MSMA
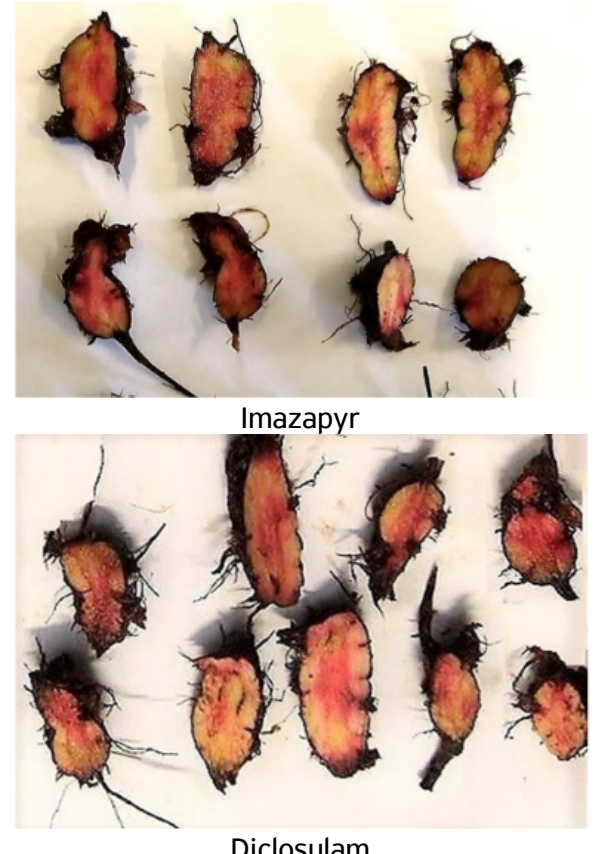

Diclosulam

Figure 1. Coloring of $C$. rotundus tubers, at 90 DAA of treatments, subjected to $0.5 \%$ tetrazolium for $24 \mathrm{~h}$ and maintained in a germinator with constant temperature of $35^{\circ} \mathrm{C}$ in the dark. 
The number of epigeal manifestations of all treatments was lower than the control from 45 DAA. However, even with a good shoot control, the highest reduction in tuber viability was obtained in the treatments with sulfentrazone, imazapic, halosulfuron, ethoxysulfuron, and MSMA, all with scores of 3 (31 to $60 \%$ of staining in the bud and central regions). MARTINS et al. (2009) observed that the control of $C$. rotundus was over $90 \%$ when the herbicides sulfentrazone (800 and 1,000 $\mathrm{g}$ ai $\cdot \mathrm{ha}^{-1}$ ) and diclosulam (200 and $250 \mathrm{~g}$ ai $\cdot \mathrm{ha}^{-1}$ ) were used in preemergence. Both herbicides reduced the number of germinated tubers ( 0 to $10 \mathrm{~cm}$ deep) for all tested rates at 110 DAA. However, the highest reductions were observed at rates of 1,000 and $250 \mathrm{~g}$ ai $\cdot \mathrm{ha}^{-1}$ for sulfentrazone and diclosulam, respectively.

Treatments with the herbicides sulfentrazone, imazapic, halosulfuron, ethoxysulfuron, and MSMA provided the highest reductions in tuber viability. In a study carried out under field and greenhouse conditions, PASTRE et al. (2009) found that the rate of $800 \mathrm{~g}$ ai $\cdot \mathrm{ha}^{-1}$ of the herbicide sulfentrazone reduced the $C$. rotundus tuber viability by $17.5 \%$ at 90 DAA when applied in the initial postemergence ( 4 to 5 leaves).

Sulfentrazone at rates of 600,700 , and $800 \mathrm{~g}$ ai $\cdot \mathrm{ha}^{-1}$ reduced the number of viable tubers of $C$. rotundus to zero at 28 DAA (2 to 3 true leaves) (SIMPLÍCIO et al., 2018). In the present study, sulfentrazone at the rate of $800 \mathrm{~g}$ ai $\cdot \mathrm{ha}^{-1}$ reduced the number of epigeal manifestations, number of tubers + bulbs, number of bulbs, and shoot dry matter of $C$. rotundus at $45,60,75$, and $90 \mathrm{DAA}$.

The number and dry matter of viable tubers were reduced at all densities $\left(6,18,24,30\right.$, and 36 tuber $^{-}$pot $^{-1}$, corresponding to $133.3,399.9,533.2,665.5$, and 799.8 tubers $\cdot \mathrm{m}^{-2}$, respectively) under the preemergence application of sulfentrazone (800 $\mathrm{g}$ ai $\left.\cdot \mathrm{ha}^{-1}\right)$, imazapic (147 $\mathrm{g}$ ai $\left.\cdot \mathrm{ha}^{-1}\right)$, or halosulfuron $\left(112.5 \mathrm{~g}\right.$ ai $\left.\cdot \mathrm{ha}^{-1}\right)$ compared to the control. The lowest number of viable tubers was observed for treatments with sulfentrazone

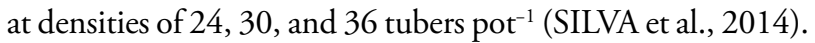

Halosulfuron is a selective herbicide recommended for application in total area in both plant cane and ratoon due to the high product selectivity to the crop. The rate used to control C. rotundus should be $112.5 \mathrm{~g}$ ai $\cdot \mathrm{ha}^{-1}$, applied when the weed is at the end of the vegetative stage or beginning of flowering, but under no water stress (RODRIGUES; ALMEIDA, 2011). The control of purple nutsedge was observed in the present study with the recommended rate, i.e., when the weed was at its full vegetative development ( 4 to 5 leaves).

Treatments with halosulfuron and 2,4-D reduced the shoot dry matter and number of epigeal manifestations of purple nutsedge plants but resulted in lower tuber viability (score of 3 ) than 2,4-D (score of 4). According to MASCARENHAS et al. (1995), halosulfuron at rates of $93.75,112.5$, and $131.25 \mathrm{~g}$ ai $\cdot \mathrm{ha}^{-1}$ was effective in reducing the viability of $C$. rotundus tubers at 90 DAA, unlike that observed for 2,4-D (1,340 $\mathrm{g}$ ae $\left.\cdot \mathrm{ha}^{-1}\right)$, with only $23 \%$ of affected tubers. The herbicides also provided a reduction in the number of epigeal manifestations compared to the control, with lower values for the highest halosulfuron rate at $60 \mathrm{DAA}$.

All treatments reduced the number of epigeal manifestations, number of bulbs, weight of tubers + bulbs, and shoot the dry matter of $C$. rotundus at 90 DAA. Plants submitted to sulfentrazone application emerged with symptoms and, subsequently, became necrotic, leading to their death. On the other hand, diclosulam, imazapic, and imazapyr acted by inhibiting the emergence of this species. Plants susceptible to sulfentrazone emerge from the treated soil, become necrotic, and die when exposed to light (RODRIGUES; ALMEIDA, 2018). NOVO et al. (2008a) also observed that purple nutsedge plants treated with sulfentrazone emerged from the soil, became necrotic, and died when exposed to light.

The herbicide MSMA provided a low number of epigeal manifestations, shoot dry matter, number of tubers and bulbs, weight of tubers + bulbs, and tuber viability compared to the control even with a low percentage of control at 90 DAA (56.25\%). FOLONI et al. (2008) found that the use of MSMA in the total area followed by directed spraying (32 days after the first application) provided control over $97 \%$ at 60 DAT. However, only one application in the total area at rates of 2,400 and $1,920 \mathrm{~g}$ ai $\cdot \mathrm{ha}^{-1}$ promoted controls of 88.7 and $78.7 \%$, respectively. In addition, MSMA reduced the number of healthy tubers, being required two sequential applications.

Leaf application of MSMA $\left(2,240 \mathrm{~g}\right.$ ai $\left.\cdot \mathrm{ha}^{-1}\right)$ reduced the number of sprouts of $C$. rotundus and Cyperus esculentus by $60 \%$ at 60 DAT. However, the reduction reached $66 \%$ when it was applied via soil + leaf and $10 \%$ only via soil. Leaf and leaf + soil applications reduced root weight by more than $59 \%$, but the reduction reached only $12 \%$ when the target was the soil (MCELROY et al., 2003). Absorption of MSMA occurs through the leaf, leading to symptoms of chlorosis and necrosis (RODRIGUES; ALMEIDA, 2018). Symptoms of chlorosis and necrosis in $C$. rotundus leaves and a reduction in the number of epigeal manifestations were observed in the present study.

NOVO et al. (2008a) studied the effectiveness of the herbicide sulfentrazone ( $700 \mathrm{~g}$ ai $\cdot \mathrm{ha}^{-1}$ ) to control of $C$. rotundus and found a lower number of sprouts and tubers, as well as lower fresh and dry biomass of the root, shoot, and tubers, than the control. In the present study, sulfentrazone ( $800 \mathrm{~g}$ ai $\left.\cdot \mathrm{ha}^{-1}\right)$ provided a reduction in the number of epigeal manifestations, number of bulbs, weight of tubers + bulbs, shoot dry matter, and tuber viability even with high control at 90 DAA.

The herbicide imazapic is also used to control the preemergence of $C$. rotundus in sugarcane. The use of $110 \mathrm{~g}$ ai $\cdot \mathrm{ha}^{-1}$ was sufficient to maintain the percentage of soil cover below $5 \%$ compared to the control treatment without application at 10 DAA. Moreover, tubers exposed on the soil surface combined with the use of this herbicide resulted in 
a lower percentage than the control, which reached around $40 \%$ at $60 \mathrm{DAA}$ and $60 \%$ at $130 \mathrm{DAA}$. In addition, imazapic reduced the number, dry matter, and viability of tubers, besides decreasing the shoot dry matter of purple nutsedge plants (AZANIA et al., 2006), which corroborates the results observed in the present study.

Tuber viability and height of purple nutsedge plants were reduced when using the herbicide imazapic $\left(122.5 \mathrm{~g}\right.$ ai $\left.\cdot \mathrm{ha}^{-1}\right)$ compared to the control (NOVO et al., 2008b). In the present study, imazapic reduced the number of epigeal manifestations, number of tubers and bulbs, weight of tubers + bulbs, shoot dry matter, and tuber viability.

Studies on tuber viability are essential to assist in the choice of herbicides, as these products, in addition to controlling the shoot, need to be able to be translocated to the tubers to make them unviable and avoid new emergence flows. According to DURIGAN et al. (2005), herbicides that make tubers unviable guarantee a gradual disinfestation of the area.
The control of the weed shoot may be sufficient in a single crop cycle, but the control needs to reach the chain of $C$. rotundus tubers in the long term, thus reducing the infestation of propagules in the soil.

\section{CONCLUSIONS}

The preemergence application of the herbicides sulfentrazone

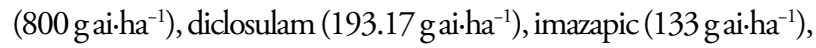
and imazapyr $\left(500 \mathrm{~g} \mathrm{ae} \mathrm{ha}^{-1}\right)$ and the postemergence application of halosulfuron (112.5 g ai.ha $\left.{ }^{-1}\right)$, ethoxysulfuron (135 $\mathrm{g}$ ai $\left.\cdot \mathrm{ha}^{-1}\right)$, MSMA (1,975 g ai.ha $\left.{ }^{-1}\right)$, and 2,4-D (1,340 $\mathrm{g}$ ae $\left.\cdot \mathrm{ha}^{-1}\right)$ reduced the number of epigeal manifestations, weight of tubers + bulbs, number of bulbs, and shoot dry matter of $C$. rotundus. Sulfentrazone, imazapic, halosulfuron, ethoxysulfuron, and MSMA were the most effective treatments in reducing tuber viability.

ACKNOWLEDGEMENTS: Not applicable.

FUNDING: This work did not receive any specific grant from funding agencies in the public, commercial, or not-for-profit sectors.

CONFLICTS OF INTEREST: All authors declare that they have no conflict of interest.

ETHICAL APPROVAL: Not applicable.

AVAILABILITY OF DATA AND MATERIAL: All data generated or analyzed during this study are included in this published article.

AUTHORS' CONTRIBUTIONS: Conceptualization: Giraldeli, A.L.; Victoria Filho, R. Data curation: Giraldeli, A.L.; Silva,

A.F.M.; Brito, F.C.B.; Lima, R.J.N.; Santos, B.S.; Oliveira, D.A.G. Formal analysis: Silva, A.F.M.; Giraldeli, A.L. Writing - original draft: Giraldeli, A.L.; Silva, A.F.M. Writing - review \& editing: Giraldeli, A.L.; Silva, A.F.M.; Brito, F.C.B.; Lima, R.J.N.; Santos,

B.S.; Oliveira, D.A.G.; Victoria Filho, R.

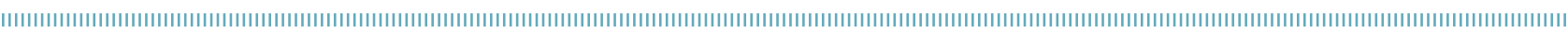

\section{REFERENCES}

ASOCIACION LATINOAMERICANA DE MALEZAS (ALAM). Recomendaciones sobre unificación de los sistemas de evaluación em ensayos de control de malezas. Bogotá: ALAM, 1974. p.35-38.

AZANIA, C.A.M.; AZANIA, A.A.P.M.; PAVANI, M.C.M.D.; ALVES, P.L.C.A. Desenvolvimento da tiririca (Cyperus rotundus) influenciado pela presença e ausência de palha de cana-de-açúcar e herbicida. Planta Daninha, Viçosa, v.24, n.1, p.29-35, 2006. https://doi. org/10.1590/SO100-83582006000100004

BALOCH, A.H.; REHMAN, H.; IBRAHIM, Z.; BUZDAR, M.A.; AHMAD, $\mathrm{S}$. The biology of Balochistani weed: Cyperus rotundus Linnaeus. A Review. Pure and Applied Biology, Quetta, v.4, n.2, p.171-180, 2015. https://doi.org/10.19045/bspab.2015.42005

BANGARWA, S.K.; NORSWORTHY, J.K.; JHA, P.; MALIK, M. Purple nutsedge (Cyperus rotundus) management in an organic production system. Weed Science, New York, v.56, n.4, p.606-613, 2008. https://doi.org/10.1614/WS-07-187.1
DURIGAN, J.C.; CORREIA, N.M.; TIMOSSI, P.C. Estádios de desenvolvimento e vias de contato e absorção dos herbicidas na inviabilização de tubérculos de Cyperus rotundus. Planta Daninha, Viçosa, v.23, n.4, p.621-626, 2005. https://doi.org/10.1590/ so $100-83582005000400009$

FOLONI, L.L.; CHRISTOFFOLETI, P.J.; CARVALHO, S.J.P.; NICOLAI, M. Programa de manejo da tiririca (Cyperus rotundus) na cultura da cana-de-açúcar com aplicação isolada ou seqüencial de MSMA. Planta Daninha, Viçosa, v.26, n.4, p.883-892, 2008. https://doi.org/10.1590/ so $100-83582008000400020$

MARTINS, D.; TOMAZELA, M.S.; DAVID, D.V.; MARTINS, C.C. Controle de tiririca com sulfentrazone e diclosulam e viabilidade de tubérculos em diferentes profundidades de solo. Bragantia, Campinas, v.68, n.2, p.357-366, 2009. https://doi.org/10.1590/ s0006-87052009000200009 
MASCARENHAS, M.H.T.; GALLI, A.J.B.; VIANA, M.C.M.; MACÊDO, G.A.R.; LARA, J.F.R. Eficácia do halosulfuron no controle de tiririca (Cyperus rotundus) na cultura da cana-de-açúcar. Planta daninha, Viçosa, v.13, n.2, p.69-80, 1995. https://doi.org/10.1590/ S0100-83581995000200002

MCELROY, J.S.; YELVERTON, F.H.; TROXLER, S.C.; WILCUT, J.W. Selective exposure of yellow (Cyperus esculentus) and purple nutsedge (Cyperus rotundus) to postemergence treatments of CGA-362622, imazaquin and MSMA. Weed Technology, New York, v.17, n.3, p.554-559, 2003. https://doi.org/10.1614/WTO2-156

MONQUERO, P.A.; HIRATA, A.C.S. Comportamento de herbicidas nas plantas. In: MONQUERO, P.A. (org). Aspectos da biologia e manejo das plantas daninhas. São Carlos, SP: RiMa, 2014.

NOVO, M.C.S.S.; VICTORIA FILHO, R.; LANGBECK, F.M.; LAGO, A.A.; DEUBER, R.; ROLIM, G.S. Efeito de sulfentrazone no sistema integrado palha de cana-de-açúcar, herbicida e vinhaça no desenvolvimento inicial da tiririca (Cyperus rotundus). Revista Brasileira de Herbicidas, Londrina, v.7, n.1, p.1-14, 2008a. https://doi.org/10.7824/rbh.v7i1.58

NOVO, M.C.S.S.; VICTORIA FILHO, R.; LANGBECK, F.M.; LAGO, A.A.; DEUBER, R.; ROLIM, G.S. Interação de imazapic no sistema integrado palha de cana-de-açúcar, herbicida e vinhaça no crescimento inicial da tiririca. Planta Daninha, Viçosa, v.26, n.2, p.439-449, $2008 \mathrm{~b}$. https://doi.org/10.1590/SO100-8358200800020002 1

PASTRE, W.; DEUBER, R.; ROLIM, J.C. Viabilidade de tubérculos de tiririca (Cyperus rotundus) tratados com sulfentrazone e flazasulfuron. Revista Brasileira de Herbicidas, Londrina, v.8, n.2, p.44-53, 2009. https://doi.org/10.7824/rbh.v8i2.67

PEERZADA, A.M. Biology, agricultural impact and management of Cyperus rotundus L.: the world's most tenacious weed. Acta Physiologiae Plantarum, Heidelberg, v.39, n.12, p.270, 2017. https://doi.org/10.1007/s1 1738-017-2574-7

PIMENTEL-GOMES, F.; GARCIA, C.H. Estatística aplicada a experimentos agronômicos e florestais: exposição com exemplos e orientações para uso de aplicativos. Piracicaba: FEALQ, 2002.
RAHNAVARD, A.; ASHRAFI, Z.Y.; RAHBARI, A.; SADEGHI, S. Effect of different herbicides on control of purple nutsedge (Cyperus rotundus L.). Pakistan Journal of Weed Science Research, Peshawar, v. 16, n. 1, p.57-66, 2010.

RODRIGUES, B.N.; ALMEIDA, F.S. Guia de herbicidas. Londrina: Authors Edition, $2011.697 p$.

RODRIGUES, B.N.; ALMEIDA, F.S. Guia de herbicidas. Londrina: Authors Edition, 2018. 764p.

SILVA, F.M.L.; VELINI, E.D.; ROSSI, C.V.S.; NEGRISOLI, E.; CORREA, M.R. Metodologia para determinar a viabilidade de tubérculos de Cyperus rotundus. Revista Brasileira de Herbicidas, Londrina, v.8, n.1, p.1-10, 2009. https://doi. org/10.7824/rbh.v8i1.62

SILVA, B.P.; ALMEIDA, R.O.; SALGADO, T.P.; ALVES, P.L.C.A. Efficacy of imazapic, halosulfuron and sulfentrazone for Cyperus rotundus L. control in response to weed tuber density. African Journal of Agricultural Research, Lagos, v.9, n.47, p.34583464, 2014. Available from: https://academicjournals.org/ journal/AJAR/article-abstract/39AB30C48597. Access on: 15 Nov. 2018

SIMONI, F.; VICTORIA FILHO, R.; SAN MARTIN, H.A.M.; SALVADOR, F.L.; ALVES, A.S.R.; BREMER NETO, H. Eficácia de imazapic e sulfentrazone sobre Cyperus rotundus em diferentes condições de chuva e palha de cana-de-açúcar. Planta Daninha, Viçosa, v.24, n.4, p.769-778, 2006. https://doi.org/10.1590/ So $100-83582006000400018$

SIMPLÍCIO, F.J.T.; ESPOSTI, C.D.; TOFFOLI, C.R.; SILVA, D.G.; KUVA, M.A. Herbicide sulfentrazone in the control of weed plants in initial posts-emergency of sugarcane crop. Applied Research () Agrotechnology, Guarapuava, v.11, n.1, p.99-103, 2018. Available from: https://revistas.unicentro.br/index.php/repaa/ article/view/5174. Access on: 19 Nov. 2018.

TUKEY, J.W. Comparing individual means in the analysis of variance. Biometrics, Hoboken, v.5, n.2, p.99-1 14, 1949. https:// doi.org/10.2307/3001913 